\title{
QUALITY OF LIFE AND DEPRESSIVE SYMPTOMS AMONG ELDERLY IN PRIMARY CARE
}

\author{
QUALIDADE DE VIDA E SINTOMAS DEPRESSIVOS ENTRE IDOSOS DA \\ ATENÇÃO PRIMÁRIA
}

\section{Rosmarie HAJJAR ${ }^{1}$; Giovanna Gaudenci NARDELLI' ${ }^{2}$ Luan Augusto Alves GARCIA ${ }^{3}$; Eliana Maria GAUDENCI ${ }^{4}$; Álvaro da Silva SANTOS ${ }^{5}$}

1. Farmacêutica e Mestre em Psicologia pelo Programa de Pós-Graduação em Psicologia da Universidade Federal do Triângulo Mineiro, Uberaba, MG, Brasil. rhajjar@ terra.com.br; 2. Enfermeira, Mestre e Doutoranda pelo Programa de Pós-Graduação em Atenção à Saúde da Universidade Federal do Triângulo Mineiro, Uberaba, MG, Brasil; 3. Enfermeiro, Mestre e Doutorando pelo Programa de PósGraduação em Atenção à Saúde da Universidade Federal do Triângulo Mineiro, Uberaba, MG, Brasil; 4. Enfermeira e Mestre em Atenção à Saúde pelo Programa de Pós-Graduação em Atenção à Saúde da Universidade Federal do Triângulo Mineiro, Uberaba, MG, Brasil; 5. Enfermeiro, Doutor e Professor Associado do curso de Graduação em Enfermagem da Universidade Federal do Triângulo Mineiro, Uberaba, MG, Brasil.

\begin{abstract}
To evaluate the perception of quality of life (QoL) and its relationship to socioeconomic variables and depressive symptoms in elders that use Primary Care. Methods: this is an analytical, descriptive, quantitative and cross-sectional study conducted in 2016 and 2017 with 248 senior citizens registered in the Primary Health Care Units of the city of Uberaba, MG. A sociodemographic questionnaire was used, together with the Mini-Mental State Examination, the Geriatric Depression Scale, the WHOQOL-Bref and the WHOQOL-Old. The psychological domain had the highest score and the environmental the lowest. Their score on the WHOQOL-Old was 64.9, the highest score was in the intimacy facet and the lowest in the social participation one. The variables gender, age, education, income, occupation, religion, and having a partner affected the physical, psychological and social domains of the WHOQOL-Bref, and the facets autonomy, death or dying, intimacy and sensory function affected the WHOQOL-Old. Depressive symptoms, observed in $32.7 \%$ of the elders, influenced all domains of the WHOQOL-Bref and all facets of the WHOQOL-Old. Depressive symptoms were strong predictors of the worse scores of quality of life perception in both instruments. The results found can guide interventions to minimize depressive symptoms, positively impacting the perception of QoL.
\end{abstract}

KEYWORDS: Quality of life. Depression. Primary health care.

\section{INTRODUCTION}

Human development made it possible to increase life expectancy and extend experiences along the aging process. However, although this process is commonly associated to the diminution of physical and cognitive capabilities, greater vulnerabilities, degenerative processes and growing dependency, it is heterogeneous, which means it can be understood in a variety of ways.

A study conducted with the North-American population, with groups of 51 years old or older people, evaluated well-being indexes, noting that $48 \%$ of those who were between 51 and 54 years of age and $28 \%$ of those who were 85 years of age or more reported the state of their health as great or very good. On the other hand, $89 \%$ of the adults between 51 and 54 years of age and $56 \%$ of elders above 85 reported limitations regarding their health at work and at home (LOWSKY et al., 2014).

Thus, many adult individuals had their health meaningfully compromised, which lead to a demystification of the idea of aging characterized by an increase in limitations and health decline. The study suggests that it is time to reconsider the importance of chronological aging and establish social policies that reflect better the conditions of health and well-being throughout the life of the population1. This view is adopted by the World Health Organization (WHO), which conceptualizes active aging as the "process of optimizing health opportunities, participation and safety, to improve the quality of life as people grow older" (WHO, 2015).

However, although aging does not necessarily indicate deficiency or a decline in health, the elder population is more vulnerable. In developed countries, such as Canada, it was found that $33 \%$ of the elders who are 65 or older presented some type of disability, and that number was increased to $44 \%$ among those who were 75 years of age or older (POLICY SUMMARY OF THE CANADIAN MEDICAL ASSOCIATION, 2013). In developing countries, such as Brazil, social factors, such as nutrition, residence and education, can generate a negative impact in the health production of elders (GEIB, 2012). 
It becomes important to establish ways to evaluate the aging process and, to that end, the concept of Quality of Life (QoL) emerges, defined by the WHO as "a perception of the individual, of their position in life, in the context of the culture and value systems in which they live and their relationship with their objectives, expectancies, standards and preoccupations" (WHO, 2001).

The QoL is a construct whose definition is influenced by cultural, ethical, religious and personal aspects, and is related to individual perception. There is a consensus regarding their multidimensional aspect, which involves subject parameters such a well-being, happiness, personal conquests, and objective parameters, such as the satisfaction of basic needs and those that emerge from the social structure available (FLECK, M. P.; CHACHAMOVICH, E.; TRENTINI, C., 2006).

The perception of the elders regarding their QoL is strongly associated to their health, and there are also references to the importance of positive feelings, personal relationships, and nutrition. Thus the higher the number of morbidities the lower were the scores of QoL perception (PASKULIN et al, 2010).

Among the chronic non-transmissible diseases, depression stands out as the most prevalent mental illness among the elderly. It is characterized by mood swings, losses of interest and pleasure, changes in sleep and appetite, tiredness, lower selfesteem, feelings of uselessness, and diminished focus (WORLD HEALTH ORGANIZATION, 2012).

According to the Diagnostic and Statistical Manual of Mental Disorders (DSM-V), depression is called major depressive disorder and it can present itself in a softer but chronic way, in which case it is classified as dysthymia. It is called nonspecified depressive disorder when depressive symptoms with clinical meanings exist, but are not according to other definitions (AMERICAN PSYCHIATRIC ASSOCIATION, 2014). Depressive symptoms can be identified in many scales, with changeable intensities, and can provoke changes in social and occupational development, or even include feelings of guilt and, in the worst cases, thoughts of death or suicide (OLIVEIRA et al, 2013).

A study with elders from the rural zone of the city of Uberaba-MG who presented signs of depression revealed changes in their perception of QoL in many aspects of their lives (RODRIGUES et al, 2016). Another study conducted in Sete Lagoas, MG, with 2052 elders, showed an association between the absence of depressive symptoms and good QoL (CAMPOS et al, 2014).

Primary Health Care, supported by the Family Health Strategy (ESF), must face the serious challenge that of mental health problems through the implementation of actions, reorganizing work as to offer specific technical support in mental health, incorporating more appropriate interventions, as welcoming the patients and offering qualified listening, allowing for a broader comprehension of the health-sickness concepts in the primary health service network of Unified Health System (TANAKA; RIBEIRO, 2009).

Considering that population aging constitutes a challenge for the management of public policies in Brazil, evaluating the QoL in this population is extremely important, since it constitutes a right of the elder, according to the Elder Statute and the National Policy of the Elder (MINISTÉRIO DA SAÚDE, 2009; CARVALHO, 2011).

Despite the intimate association of depression and the negative perception of the quality of life, it is possible to find variations regarding the aspects affected in each population, and the evaluation of the perception of QoL becomes important so one can observe the extension of the repercussions of these symptoms (LIMA; FLECK, 2009).

In this sense, this study aimed to evaluate the quality of life and its relation to the socioeconomic variables and depressive symptoms among elders who use the Primary Care services.

\section{MATERIAL AND METHODS}

This is an analytical, exploratory, crosssectional and quantitative study, which is part of a larger project called "Quality of life and profile of elders in the Primary Health Care of a municipality in the countryside of Minas Gerais". It involved 248 elders (60 years old or older) registered in the Primary Health Care Units of the city of Uberaba, MG, whose cognitive functions were satisfactory according to the results of a Mini-Mental State Examination (MMSE), applied according to their educational level.

The size of the sample considered as a dependent variable the psychological domain of the WHOQOL-Bref instrument, with a determination coefficient of $\mathrm{R}^{2}=0.10$, in a model of multiple linear regression with seven predictors and a level of significance (p) of 0.01 , beta error of 0.1 , and statistical power of $90 \%$. The minimum sample size of 228 interviews was found through the PASS 
(Power Analysis and Sample Size) software, version 14 , and $20 \%$ was added to that number to compensate for sample losses, to a total of 273 elders.

The sample selection was done by convenience and collection was conducted by a trained team, from November 2016 to May 2017, on all urban Primary Health Care Units of Uberaba. The interviews occurred in a private room in the Primary Health Care Units, or in the homes of elders who preferred that way. The following instruments were used: a questionnaire with sociodemographic data, health conditions and life habits, the Geriatric Depression Scale, the WHOQOL-Bref and the WHOQOL-Old.

The Geriatric Depression Scale - GDS-15, in its abbreviated version, includes yes or no questions, evaluating symptoms of mood changes, feelings of helplessness, uselessness, lack of interest, tedium and happiness. This scale was validated for Brazilian elders, considering the presence of depressive symptoms with scores above 5 , a sensibility of $85.4 \%$, specificity of $73.9 \%$ and reliability of 0.81 (ALMEIDA; ALMEIDA, 2009).

The WHOQOL-Bref, validated for the Brazilian population, evaluates QoL through 26 questions that compose the following domains: physical, psychological, social and environmental. The Answers are presented on a Likert scale, from 1 to 5 , and the results on a scale from 0 to 100 (FLECK et al, 2000). The WHOQOL-Old, a complementary module of the WHOQOL-Bref for the elderly population, was validated in Brazil, and is formed of 24 questions, distributed in 6 facets: autonomy; social participation; past, present and future activities; death and dying; intimacy; and functioning of the senses. They are also presented on a Likert scale of 5 options, the validation of this instrument for the Brazilian population showed it to have adequate internal consistence (Cronbach Coefficient: 0.71 to 0.88 ), discrimination validity $(\mathrm{p}<0.01)$, concurrent validity (correlation coefficient from -0.61 to -0.50$)$ and test retest reliability (correlation coefficient from 0.58 to 0.81 ) (FLECK, M. P.; CHACHAMOVICH, E.; TRENTINI, C., 2006).

The study has respected the formal demands of national and international norms that regulate researches involving human beings, and was approved by the Research Ethics Committee of the Federal University of the Triângulo Mineiro (protocol $\mathrm{n}^{\circ}$ 1.604.573).

Data from the questionnaires were typed on the Microsoft Excel@ software, through dual input performed by different people, and then transported to the software Statistical Package for Social Sciences (SPSS), 20.0.

For the exploratory analysis of data, absolute (n) and relative (\%) frequencies were calculated, as well as measures of central tendency (means) and dispersion (standard deviation), considering the relevant variables for the characterization of the elders who participate in the study.

For the correlation between the perception of quality of life and the sociodemographic variables, the t-test was used for independent samples, with a significance level of $0.01(\mathrm{p} \leq 0.01)$.

To confirm the relationship between predicting variables and quality of life, a multiple linear regression was used, with seven predictors (gender, age, educational level, income, occupation, partner, and the presence of depressive symptoms), chosen according to the literature and to the results of the analysis of the t-test, for variables whose pvalue was lower than 0.2 . In addition, all prerequisites for the use of the regression model, such as residue analysis, atypical numbers and multiple co-linearity were considered.

\section{RESULTS}

Among the elders who participated in this study, there was a predominance of females $(68.5 \%)$ and approximately half $(51.2 \%)$ had studied for four years or less. A high percentage of these elders were also characterized by an income that was usually below 4 minimum wages $(89.5 \%)$ and had a religion $(94.8 \%)$. Most of them $(62.9 \%)$ were retired and declared to have a partner $(52.4 \%)$.

Through the WHOQOL-Bref, the averages in the psychological domain stood out as the highest (67.3) and those in the environmental domain, as the lowest (58.6). Through the WHOQOL-Old, the perception of QoL of the elders was higher in the facet intimacy (68.3) and lower in the facet social participation (62.1), according to Table 1 .

The sociodemographic variables that were shown to influence, in the bivariate analysis, the physical domain of the WHOQOL-Bref, were income and occupation. Lower income and activity had the lowest averages in the perception of QoL. The psychological domain was influenced by gender and educational level, being that the female gender and an educational level below four years of study had the lowest averages. Having a partner generated a better QoL perception in the social domain, according to Table 2 . 
Table 1. Perception of Quality of Life among Elders, Uberaba (MG), Brazil, 2017. ( $\mathrm{n}=248)$

\begin{tabular}{lcc}
\hline & Average & Standard Deviation \\
\hline WHOQOL- Bref - Domains & & 13.8 \\
Global & 62.6 & 17.2 \\
Physical & 61.2 & 17.5 \\
Psychological & 67.3 & 18.3 \\
Social & 65.1 & 12.9 \\
Environmental & 58.6 & \\
WHOQOL-OLD - Facets & & 15.0 \\
Global & 64.9 & 17.8 \\
Autonomy & 65.5 & 17.0 \\
Past, Pres. and Fut. Activities & 65.9 & 17.5 \\
Social Participation & 62.1 & 27.9 \\
Death or Dying & 63.3 & 21.6 \\
Intimacy & 68.3 & 24.6 \\
Sensory Function & 66.2 & \\
\hline
\end{tabular}

Table 2. Sociodemographic data and domains of the WHOQOL-Bref among elders, Uberaba, (MG), Brazil, 2017. $(n=248)$

\begin{tabular}{|c|c|c|c|c|c|c|c|c|}
\hline & \multicolumn{8}{|c|}{ WHOQOL- Bref - Domains } \\
\hline & \multicolumn{2}{|c|}{ Physical } & \multicolumn{2}{|c|}{ Psychological } & \multicolumn{2}{|c|}{ Social } & \multicolumn{2}{|c|}{ Environmental } \\
\hline & Average & SD & Average & SD & Average & SD & Average & SD \\
\hline \multicolumn{9}{|l|}{ Gender } \\
\hline Male & 65.1 & 16.2 & $71.8^{*}$ & 15.1 & 66.1 & 18.3 & 61.6 & 13.3 \\
\hline Female & 59.5 & 17.3 & $65.3^{*}$ & 18.2 & 64.7 & 18.4 & 57.2 & 12.6 \\
\hline \multicolumn{9}{|l|}{ Age } \\
\hline 60 to 79 & 61.4 & 17.4 & 66.9 & 17.4 & 65.2 & 18.5 & 58.4 & 13.1 \\
\hline Over 79 & 58.9 & 14.7 & 71.7 & 18.7 & 63.6 & 16.9 & 60.2 & 10.7 \\
\hline \multicolumn{9}{|l|}{ Education } \\
\hline $\begin{array}{l}3 \text { years study or } \\
\text { less }\end{array}$ & 59.2 & 16.8 & $63.9^{*}$ & 17.9 & 62.6 & 18.7 & 58.3 & 12.5 \\
\hline $\begin{array}{l}4 \text { years study o } \\
\text { more }\end{array}$ & 63.2 & 17.3 & $71.7^{*}$ & 15.8 & 68.3 & 17.4 & 59.3 & 13.4 \\
\hline \multicolumn{9}{|l|}{ Income } \\
\hline Up to $3 \mathrm{MW}$ & $60.2^{*}$ & 17.1 & 66.8 & 17.8 & 64.8 & 18.4 & 58.0 & 12.9 \\
\hline $4 \mathrm{MW}$ or more & $73.5^{*}$ & 12.4 & 75.6 & 10.7 & 69.6 & 12.5 & 63.4 & 11.2 \\
\hline \multicolumn{9}{|l|}{ Occupation } \\
\hline Less active & $59.2 *$ & 17.3 & 66.4 & 18.1 & 65.2 & 17.9 & 58.6 & 12.9 \\
\hline More active & $69.6^{*}$ & 13.2 & 71.6 & 14.1 & 65.7 & 19.8 & 58.9 & 13.1 \\
\hline \multicolumn{9}{|l|}{ Partner } \\
\hline No & 60.8 & 16.1 & 67.7 & 16.9 & $62.3^{*}$ & 19.4 & 57.8 & 12.8 \\
\hline Yes & 61.4 & 18.1 & 67.0 & 18.2 & $68.0^{*}$ & 16.6 & 59.4 & 13.0 \\
\hline \multicolumn{9}{|l|}{ Religion } \\
\hline $\begin{array}{l}\text { Cathol. } \\
\text { Evang. }\end{array}$ & 60.3 & 16.7 & 66.5 & 17.8 & 65.1 & 18.0 & 57.9 & 12.5 \\
\hline Other & 64.0 & 18.1 & 70.8 & 17.2 & 65.7 & 17.2 & 61.4 & 14.9 \\
\hline
\end{tabular}

SD - Standard Deviation; * $\mathrm{p} \leq 0.01$

Through the WHOQOL-Old evaluation, the less active elders had the lowest results in the autonomy facet; those from 60-79 and the catholic and evangelical elders had the lowest results in the death and dying facet; those who did not have a partner had the lowest results in the intimacy facet; and those between 60 and 79 years of age had the lowest ones in the facet sensorial functioning.

From the 248 elders interviewed in the Primary Health Care Units, $32.7 \%$ presented depressive symptoms. All WHOQOL-Bref domains and WHOQOL-Old facets were negatively affected by depressive symptoms, as shown in Table 3.

After a multiple linear regression analysis, considering the sociodemographic predictors and the depression index, all WHOQOL-Bref domains (Table 4) and WHOQOL-Old facets (Table 5) were strongly and negatively affected by the presence of depressive symptoms. In addition, lower educational levels had a negative influence on the psychological 
levels, and not having a partner affected the social domain and the Intimacy facet, both in a negative way.

Table 3. Sociodemographic data and facets of the WHOQOL-Old among elders, Uberaba, (MG), Brazil, 2017.

\begin{tabular}{|c|c|c|c|c|c|c|c|c|c|c|c|c|}
\hline & \multicolumn{12}{|c|}{ WHOQOL-OLD - Facets } \\
\hline & \multicolumn{2}{|c|}{ Autonomy } & \multicolumn{2}{|c|}{$\begin{array}{l}\text { Past, Pres. and } \\
\text { Fut. Activities }\end{array}$} & \multicolumn{2}{|c|}{$\begin{array}{c}\text { Social } \\
\text { Participation }\end{array}$} & \multicolumn{2}{|c|}{ Death or Dying } & \multicolumn{2}{|c|}{ Intimacy } & \multicolumn{2}{|c|}{$\begin{array}{c}\text { Sensory } \\
\text { Function }\end{array}$} \\
\hline & Average & SD & Average & SD & Average & SD & Average & SD & Average & SD & Average & SD \\
\hline \multicolumn{13}{|l|}{ Gender } \\
\hline Male & 66.6 & 16.1 & 67.7 & 15.7 & 62.1 & 18.0 & 64,1 & 29,2 & 70,2 & 20,7 & 67.7 & 24.7 \\
\hline Female & 64.9 & 18.5 & 65.1 & 17.5 & 62.1 & 17.3 & 62,9 & 27,4 & 67,5 & 22,0 & 65.5 & 24.6 \\
\hline \multicolumn{13}{|l|}{ Age } \\
\hline 60 to 79 & 66.1 & 17,6 & 65,8 & 17.4 & 62.1 & 17.8 & $62,1 *$ & 28,1 & 67,9 & 21,9 & 66.6 & 24.6 \\
\hline Over 79 & 57.9 & 18.3 & 68,1 & 11,8 & 61,8 & 14,0 & $77,3^{*}$ & 21,4 & 73,4 & 18.3 & 61,8 & 24,3 \\
\hline \multicolumn{13}{|l|}{ Education } \\
\hline $\begin{array}{l}3 \text { years study } \\
\text { or less }\end{array}$ & 63,9 & 18,6 & 65,8 & 16.8 & 62,2 & 17.3 & 63,1 & 26,6 & 65.7 & 22,7 & $60,5^{*}$ & 24,3 \\
\hline $\begin{array}{l}4 \text { years study } \\
\text { or more }\end{array}$ & 67,6 & 16,5 & 66.6 & 17.3 & 62,3 & 18.0 & 63,8 & 29,4 & 71,4 & 20,2 & $72,3 *$ & 23,6 \\
\hline \multicolumn{13}{|l|}{ Income } \\
\hline Up to $3 \mathrm{MW}$ & 65,4 & 17,7 & 65,8 & 17.2 & 61,9 & 17,6 & 61,9 & 28,2 & 67,9 & 21,5 & 65,0 & 24,8 \\
\hline $\begin{array}{l}4 \mathrm{MW} \text { or } \\
\text { more }\end{array}$ & 69,2 & 11,0 & 63,5 & 11,4 & 58,7 & 16.9 & 72,6 & 23,6 & 73,6 & 14.7 & 78,4 & 21,8 \\
\hline \multicolumn{13}{|l|}{ Occupation } \\
\hline Less active & $64,1 *$ & 18.0 & 66.6 & 16.9 & 61,7 & 17.5 & 64,3 & 26,7 & 68,0 & 21.6 & 64.9 & 24,5 \\
\hline More active & $72,7 *$ & 14,0 & 63,7 & 17.2 & 64,1 & 17.4 & 57,5 & 32,7 & 69,9 & 22,0 & 72,0 & 24.7 \\
\hline \multicolumn{13}{|l|}{ Partner } \\
\hline No & 66.9 & 17.5 & 65,3 & 18.4 & 61.2 & 17,6 & 64.7 & 26,5 & $64,2 *$ & 21,1 & 66,3 & 23,1 \\
\hline Yes & 64,5 & 17,7 & 66,7 & 15,5 & 63,1 & 17.4 & 61,7 & 29,1 & $72,1 *$ & 21,5 & 66.1 & 26.01 \\
\hline \multicolumn{13}{|l|}{ Religion } \\
\hline $\begin{array}{l}\text { Cathol. and } \\
\text { Evang. }\end{array}$ & 65,0 & 14.9 & 66,3 & 16.9 & 61,9 & 17.0 & $60,4^{*}$ & 27.9 & 68,1 & 22,0 & 66.1 & 24,9 \\
\hline Other & 69,0 & 18.0 & 64.9 & 17,7 & 63,7 & 19,7 & $74.1 *$ & 27.1 & 67.0 & 20,3 & 68,6 & 21,7 \\
\hline
\end{tabular}

Table 4. The influence of depressive symptoms in the perception of Quality of Life of elders, Uberaba, (MG), Brazil, 2017. $(\mathrm{n}=248)$

\begin{tabular}{|c|c|c|c|c|c|c|}
\hline \multirow[b]{3}{*}{$\begin{array}{l}\text { WHOQOL- Bre } \\
\text { Domains }\end{array}$} & \multicolumn{2}{|c|}{$\begin{array}{c}\text { Presence of } \\
\text { depressive symptoms }\end{array}$} & \multirow{2}{*}{\multicolumn{2}{|c|}{$\begin{array}{l}\text { Difference between } \\
\text { averages (IC 95\%) }\end{array}$}} & \multirow[t]{2}{*}{ T-test } & \multirow[t]{2}{*}{$\mathbf{P}$} \\
\hline & Yes & No & & & & \\
\hline & & & & & & \\
\hline Physical & $48,6 \pm 14,3$ & $67,4 \pm 14,9$ & $-22,8$ & $-15,0$ & $-9,5$ & $<0.001$ \\
\hline Psychological & $51,5 \pm 16,0$ & $75,0 \pm 12,3$ & $-27,1$ & $-19,9$ & $-12,7$ & $<0.001$ \\
\hline Social & $54,7 \pm 19,4$ & $70,2 \pm 15,5$ & $-20,0$ & $-11,0$ & $-6,8$ & $<0.001$ \\
\hline Environmental & $50,7 \pm 14,3$ & $62,4 \pm 15,0$ & $-14,9$ & $-8,6$ & $-7,4$ & $<0.001$ \\
\hline \multicolumn{7}{|l|}{$\begin{array}{l}\text { WHOQOL-OLD } \\
\text { Facets }\end{array}$} \\
\hline Autonomy & $55,3 \pm 16,9$ & $70,5 \pm 16,0$ & $-19,6$ & $-10,9$ & $-6,9$ & $<0.001$ \\
\hline
\end{tabular}




\begin{tabular}{|c|c|c|c|c|c|c|}
\hline $\begin{array}{l}\text { Activities } \\
\text { Past Pres. Fut. }\end{array}$ & $56,5 \pm 17,1$ & $70,6 \pm 14,9$ & $-18,3$ & $-9,9$ & $-6,6$ & $<0.001$ \\
\hline Social Participation & $54,0 \pm 16,5$ & $66,0 \pm 16,6$ & $-16,5$ & $-7,6$ & $-5,3$ & $<0.001$ \\
\hline Death or Dying & $53,9 \pm 27,5$ & $67,9 \pm 27,0$ & $-21,2$ & $-6,7$ & $-3,8$ & $<0.001$ \\
\hline Intimacy & $57,4 \pm 20,7$ & $73,7 \pm 20,0$ & $-21,7$ & $-10,8$ & $-5,9$ & $<0.001$ \\
\hline Sensory Function & $55,3 \pm 24,8$ & $71,5 \pm 22,8$ & $-22,5$ & $-9,9$ & $-5,1$ & $<0.001$ \\
\hline
\end{tabular}

Table 5. Demographic variables and depressive symptoms influence in the perception of Quality of Life of elders, Uberaba, (MG), Brazil, 2017. ( $\mathrm{n}=248$ )

\begin{tabular}{|c|c|c|c|c|}
\hline & \multicolumn{4}{|c|}{ WHOQOL-Bref - Domains } \\
\hline & Physical & Psychological & Social & Environmental \\
\hline \multicolumn{5}{|l|}{ Gender } \\
\hline Beta & -0.018 & -0.048 & 0.089 & -0.054 \\
\hline $\mathrm{p}$ & 0.761 & 0.381 & 0.177 & 0.408 \\
\hline \multicolumn{5}{|l|}{ Age } \\
\hline Beta & -0.040 & 0.064 & -0.034 & 0.011 \\
\hline $\mathrm{p}$ & 0.475 & 0.219 & 0.574 & 0.858 \\
\hline \multicolumn{5}{|c|}{ Education } \\
\hline Beta & 0.040 & 0.141 & 0.114 & -0.210 \\
\hline $\mathrm{p}$ & 0,938 & 0.008 & 0.069 & 0.744 \\
\hline \multicolumn{5}{|l|}{ Income } \\
\hline Beta & 0.078 & 0.021 & -0.002 & 0.063 \\
\hline $\mathrm{p}$ & 0.188 & 0.700 & 0.969 & 0.325 \\
\hline \multicolumn{5}{|c|}{ Occupation } \\
\hline Beta & 0.118 & -0.006 & -0.540 & -0.077 \\
\hline $\mathrm{p}$ & 0.051 & 0.908 & 0.373 & 0.241 \\
\hline \multicolumn{5}{|l|}{ Partner } \\
\hline Beta & -0.006 & -0.031 & 0.175 & 0.017 \\
\hline $\mathrm{p}$ & 0.913 & 0.563 & 0.006 & 0.792 \\
\hline \multicolumn{5}{|c|}{ Depression Index } \\
\hline Beta & 0.503 & 0.599 & 0.407 & 0.408 \\
\hline $\mathrm{p}$ & $<0.001$ & $<0.001$ & $<0.001$ & $<0.001$ \\
\hline
\end{tabular}

\section{DISCUSSION}

The elders cared for in the Primary Health Care Unit presented a low level of education and income. Most were female and lived with a partner. A study conducted in the rural area of Uberaba, MG, showed a population similar to that when it comes to the characteristics: female gender $(63.6 \%)$, less than four years of study (63.2\%), income under four minimum wages (89.9\%) and married (59.9\%) (RODRIGUES et al, 2016).

The global score of perception of QoL presented by this population according to the WHOQOL-Bref was 62.2, and according to the WHOQOL-Old, 64.9. In a study conducted in Porto Alegre with 272 elders who lived in the community, according to the WHOQOL-Bref, the general score was 69.81, above what was found in this research (VITORINO; PASKULIN; VIANNA, 2013).

According to the evaluation of domains and facets of the perception of QoL, both individual and environmental aspects that are involved in the health standards of the lives of these elders stand out.

In this sense, considering the WHOQOLBref, the highest result found (67.3) was in the psychological domain, which involves the individual aspect, evaluating positive and negative feelings, the ability to think, learn, memorize and focus, self-esteem, the perception of corporal image and the acceptance of one's own appearance (FLECK et al, 2000). In a study conducted with retired elders from the public service of the government of the state of Maranhão, a high score was also observed in the psychological domain, 
albeit with a lower perception of $\mathrm{QoL}(58.3)$ (SILVA; ANDRADE, 2013).

On the other hand, the lowest average was observed in the environmental domain, which evaluates physical safety and protection, home environment, financial resources availability and quality of social and health care, opportunities to acquire new information and abilities, opportunities for leisure and recreation, physical environment and transportation, and it may reflect the influence of unfavorable social determinants, related to the low levels of instruction and income that characterize these elders (FLECK et al, 2000; GEIB, 2012).

Two studies had similar results to this one. One of them, conducted with elders who lived in the rural area of Uberaba, MG, found a lower average in the environmental domain and a higher one in the social domain (RODRIGUES et al, 2016). The other, conducted with elders cared for by two Family Health Units in João Pessoa (PB), had higher results in the social domain (73.9) and lower ones on the environmental domain (61.3) (ASSIS et al, 2015).

Through the WHOQOL-Old, the perception of QoL of the elders was higher in the facet intimacy, related to the individual aspect, to the ability of establishing personal and intimate relationships, and it should be highlighted that more than half these elders had partners. The lowest value was in the social participation facet, which evaluates routine and community activities, and can reflect, beyond the individual aspect, the deficiency of support in the social network, with diminished opportunities of leisure and social service activities (POWER; SCHMIDT, 2006; GEIB, 2012).

The physical domain of the WHOQOLBref, which refers to the evaluation of discomfort, fatigue, sleep, mobility, routine activities, work capability, and dependency of treatments and medication (FLECK et al, 2000), was meaningfully affected by lower incomes and lower activity. The autonomy facet of the WHOQOL-Old, which evaluates the ability to live independently and make your own decisions (POWER; SCHMIDT, 2006), has also shown an association to occupation, less busy elders being negatively affected.

Lower incomes and educational levels are among the social determinants that, throughout the lives of these people, lead to diminished possibilities of good nutritional conditions and adequate life habits, which will reflect in physical clinical changes and a higher need for health services (GEIB, 2012).

A study that evaluated the influence of the sociodemographic levels on the QoL perception of elders (institutionalized, hospitalized and from the community) showed a positive connection with higher activity, both in the professional aspect and in that of volunteer activities (OLIVEIRA et al, 2013). A lower activity (62.9\% of the retired elders) reflects cultural conditions of aging, characterized by inability and inactivity, distant from the conditions of health and continued activity advocated by active aging (LOWSKY et al, 2014). The female gender and the educational level influenced the psychological domain, regarding the way in which one thinks, learns, their self-esteem and corporal-perception (FLECK et al, 2000).

Educational levels also influenced the Sensory Function facet of the WHOQOL-Old, which refers to losses of sensory function and of the ability to participate in daily activities or interact with others (POWER; SCHMIDT, 2006). A higher educational level was associated to higher scores in the perception of QoL in a study conducted in the state of Rio Grande do Sul (OLIVEIRA et al, 2013).

The social domain of the WHOQOL-Bref and the Intimacy facet of the WHOQOL-Old were positively influenced by the condition of having a partner. In this evaluation, aspects regarding interpersonal relationships, social support and sexual activity are involved (POWER; SCHMIDT, 2006). In this study, $52.4 \%$ of the elders declared to have a partner, while $27.8 \%$ stated to have active sexual lives.

The facet Death and Dying of the WHOQOL-Old has shown an association with age and religion, and the younger elders (60 to 79 years of age), as well as the Catholic and evangelical elders, had lower scores of QoL perception. The facet Death or Dying refers to how the elder relates to this theme (insecurity and preoccupation in dying or feeling pain) (POWER; SCHMIDT, 2006). A different result was found in a study conducted in the state of Maranhão, in which advanced age was negatively correlated to QoL perception (SILVA; ANDRADE, 2013). Regarding religion, in this study, $78.2 \%$ were catholic or evangelical.

Among the elders cared for in the Primary Health Care Units, $32.5 \%$ presented depressive symptoms. In the bivariate analysis, there was a negative and significant correlation between the presence of depressive symptoms and the perception of QoL in all domains of the WHOQOL-Bref and all the facets of the WHOQOL-Old. The highest scores were in the social domain and in the intimacy facet, and the lowest scores in the physical domain and in the facet death or dying. In a study with elders from the rural zone of the city of UberabaMG who presented signs of depression, the highest 
scores were in the social domain and in the intimacy facet, while the lowest ones were in the environment domain and in the social participation facet (RODRIGUES et al, 2016).

A study conducted with 454 elders in Taiwan, China, showed that depressive symptoms affect in a different way the determinants of QoL perception, being that light depressive symptoms affected the physical and psychological domain while severe symptoms affected all domains, in spite of the advanced age having a protective effect in the studied population (CHANG et al, 2016).

After a regression analysis with the possible predictors, the presence of depressive symptoms negatively and significantly altered all domains of the WHOQOL-Bref and facets in the WHOQOLOld.

A study conducted with 339 elders showed an association, after a multiple linear regression, between all domains of the WHOQOL-Bref and the depression levels as evaluated by Beck's Depression Inventory and an association of the perception of QoL with gender, age, being married, social class, educational level, health perception, and more intensely, with depressive levels (TRENTINI et al, 2011). In China, the evaluation of 490 elders from the community during outpatient care also showed that depression (evaluated through EDG-15) can affect all domains and facets of the WHOQOL-Bref (CHANG et al, 2015).

A lower educational level influenced the psychological domain, and having a partner affected the social domain and the intimacy facet. On the other hand, a study comparing the elders who lived in the community in Rio Grande do Sul and institutionalized elders from Minas Gerais, showed an influence of educational level and age upon the social domain (VITORINO; PASKULIN; VIANNA, 2013).

Health determinants and well-being include genetic, socioeconomic and lifestyle factors, such as physical activities, nutrition, community involvement, social support, stress levels and professional experiences. These associated and cumulative factors will reflect in quality of life in an advanced age. The communication to the public of health repercussions throughout life can lead to the adoption of healthier atitudes (LOWSKY et al, 2014).

To prevent diseases and promote healthier and more active aging, and a consequent improvement in the QoL, the Ministry of Health offers subsidies such as the stimulation to Healthy Eating, Corporal Practices/Physical Activities and Group Work with Elders and offers as guiding instruments the Primary Care Notebook - Heath and Aging of the Elder, which, however, is underused by the professionals of Primary Care (COSTA et al, 2015).

The current health situation of the elder population cared for in Primary Care is a consequence of social inequality. Identifying the characteristics and needs of each group helps managers as well as professionals who directly act in the area, to develop specific actions to face the demands.

Depression is associated to an "increase in the risks of morbidities and mortality, to the increase in the use of health services, to the negligence in self-care and to the diminished adhesion to therapeutic treatment" (ALVARENGA; OLIVEIRA; FACCENDA, 2012). Bringing more visibility to the prevalence of depressive symptoms and their influence over the QoL can call the attention of professionals, universities and of the public sector, as to stimulate other studies which can pave the path for interventions that are appropriate for the reduction of these depressive symptoms, directly impacting the improvement of the QoL of this population.

Primary Health preventive care involves a wide range of technologies such as disease screening, immunization and vaccination, prevention of risk factors, prevention of individual biopsychological risk factors, lifestyle interventions for habit changes, nutritional orientation, orientation to physical activity, control of the consumption of tobacco, alcohol and others (MENDES, 2015).

As limitations of this study, the convenient selection of participants can be mentioned, as well as the possibility of elders who claim to be users of Primary Health Care Units, but are not. The work group tried to minimize this risk, through confirmations with community health agents, regarding the registration of the elder in family health teams.

\section{CONCLUSIONS}

Knowledge about the factors influenced by depression may help managers and other health professionals face the challenge of ensuring healthy aging for the population, reinforcing the priority of mental health of the elderly in basic care and guaranteeing citizenship and dignity, and more importantly, developing actions to prevent depression on this population.

Investments are necessary to improve the health conditions of the elderly, focusing on maintaining physical independence and autonomy 
without forgetting the economic conditions and social support.

The cross-sectional design used in the present study made it possible to identify the perception of Quality of Life and its influences in a representative sample of the elderly residents in the areas covered by the Family Health Strategy and in the traditional basic care in the urban area of Uberaba, Minas Gerais.

RESUMO: Avaliar a percepção de qualidade de vida (QV) e sua relação com variáveis socioeconômicas e sintomas depressivos em idosos que utilizam a Atenção Primária. Trata-se de um estudo analítico, descritivo, quantitativo e transversal conduzido entre os anos de 2016 e 2017 com amostra de 248 idosos cadastrados nas Unidades Básicas de Saúde do município de Uberaba, MG. Foi utilizado um questionário sociodemográfico, juntamente com o Mini-Exame do estado mental, a Escala de Depressão Geriátrica, o WHOQOL-Bref e o WHOQOL-Old. A pontuação no WHOQOL-Bref foi de 62,2. O domínio psicológico teve o maior escore e o mais baixo foi o domínio ambiente. Sua pontuação no WHOQOL-Old foi de 64,9, a pontuação mais alta na faceta de intimidade e a mais baixa na faceta participação social. As variáveis gênero, idade, educação, renda, ocupação, religião e parceiro, afetaram os domínios físico, psicológico e social do WHOQOL-Bref, e as facetas de autonomia ou morte, intimidade e função sensorial afetaram o WHOQOL-Old. Os sintomas depressivos, observados em $32,7 \%$ dos idosos, influenciaram todos os domínios do WHOQOL-Bref e todas as facetas do WHOQOL-Old. Os sintomas depressivos foram fortes preditores dos piores resultados da percepção da qualidade de vida em ambos os instrumentos. Os resultados encontrados podem orientar intervenções para minimizar os sintomas depressivos, impactando positivamente a percepção de QV.

PALAVRAS-CHAVE: Qualidade de vida. Depressão. Atenção Primária à Saúde.

\section{REFERENCES}

ALMEIDA, O. P.; ALMEIDA, S. A. Confiabilidade da versão brasileira da Escala de Depressão em Geriatria (GDS) versão reduzida. Arquivos de Neuro-Psiquiatria, São Paulo, v. 57, n. 2B, p. 421-26, 1999. http://dx.doi.org/10.1590/S0004-282X1999000300013.

ALVARENGA, M. R. M.; OLIVEIRA, M. A. D. C.; FACCENDA, O. Sintomas depressivos em idosos: análise dos itens da Escala de Depressão Geriátrica. Acta Paulista de Enfermagem, São Paulo, v. 25, n. 4, p. 497-503, 2012. http://dx.doi.org/10.1590/S0103-21002012000400003.

AMERICAN PSYCHIATRIC ASSOCIATION. DSM-5: Manual diagnóstico e -estatístico de transtornos mentais. 5th ed. Porto Alegre: Artmed Editora; 2014.

ASSIS, A. M. S. T. et al. Quality of Life and Depressive Symptoms in the Elderly Living in Community. International Archives of Medicine, v. 8, n. 246, 2015.

CAMPOS, A. C. et al. Aging, Gender and Quality of Life (AGEQOL) study: factors associated with good quality of life in older Brazilian community-dwelling adults. Health and quality of life outcomes, London, v. 12, p. 166-4, 2014.

CARVALHO, R. R. Política Nacional de Saúde da Pessoa Idosa: competência dos cuidadores de pessoas dependentes [monografia]. Brasília: Câmara dos Deputados, Centro de Formação, Treinamento e Aperfeiçoamento/Cefor, 2011.

CHANG, Y. C. et al. Depression Affects the Scores of All Facets of the WHOQOL-BREF and May Mediate the Effects of Physical Disability among Community-Dwelling Older Adults. PLoS ONE, San Francisco, v. 10, n. 5, p. e0128356, 2015.

CHANG, Y. C. et al. Levels of depressive symptoms may modify the relationship between the WHOQOLBREF and its determining factors in community-dwelling older adults. International psychogeriatrics, New York, v. 28, n. 4, p. 591-601, 2016. 
COSTA, N. R. C. D. et al. Política de saúde do idoso: percepção dos profissionais sobre sua implementação na atenção básica. Revista de Pesquisa em Saúde, São Luiz, v. 16, n. 2, p. 95-101, 2015.

FLECK, M. P. et al. Aplicação da versão em português do instrumento abreviado de avaliação da qualidade de vida "WHOQOL-bref". Revista de Saúde Pública, v. 34, n. 2, p. 178-83, 2000.

http://dx.doi.org/10.1590/S0034-89102000000200012.

FLECK, M. P.; CHACHAMOVICH, E.; TRENTINI, C. Development and validation of the Portuguese version of the WHOQOL-OLD module. Revista de Saúde Pública, São Paulo, v. 40, n. 5, p. 785-91, 2006. http://dx.doi.org/10.1590/S0034-89102006000600007.

GEIB, L. T. C. Determinantes sociais da saúde do idoso. Ciência \& Saúde Coletiva, Rio de Janeiro, v. 17, n. 1, p. 123-33, 2012. http://dx.doi.org/10.1590/S1413-81232012000100015.

LIMA, A. F. B. S.; FLECK, M. P. A. Qualidade de vida e depressão: uma revisão da literatura. Revista de Psiquiatria do Rio Grande do Sul, Porto Alegre, v. 31, n. 3, 2009. http://dx.doi.org/10.1590/S010181082009000400002.

LOWSKY, D. J. et al. Heterogeneity in healthy aging. Journals of gerontology - Series A - Biological sciences and medical sciences, Washington, v. 69, p. 640-9, 2014.

MENDES, E. V. A construção social da atenção primária à saúde. 1 ed. Brasília: Conselho Nacional de Secretários de Saúde - CONASS, 2015. 193 p.

MINISTÉRIO DA SAÚDE (BRASIL). Estatuto do Idoso. 2nd ed. Brasília: Editora do Ministério da Saúde; 2009.

OLIVEIRA, S. E. S. et al. Associations between self-perceived quality of life and socio-demographic, psychosocial, and health variables in a group of elderly. Cadernos de Saúde Pública, Rio de Janeiro, v. 29, n. 7, p. 1437-48, 2013. http://dx.doi.org/10.1590/S0102-311X2013000700017.

PASKULIN, L. M. G. et al. Percepção de pessoas idosas sobre qualidade de vida. Acta Paulista de Enfermagem, São Paulo, v. 23, n. 1, p. 101-7, 2010. http://dx.doi.org/10.1590/S0103-21002010000100016.

POLICY SUMMARY OF THE CANADIAN MEDICAL ASSOCIATION. Health and Health Care for an Aging Population. Canadá: the Canadian Medical Association; 2013.

POWER, M; SCHMIDT, S. Manual WHOQOL-OLD. Brasília: Organização Mundial da Saúde, 2006.

RODRIGUES, L. R. et al. Qualidade de vida, indicativo de depressão e número de morbidades de idosos da zona rural. Revista de Enfermagem e Atenção à Saúde, Uberaba, v. 4, n. 1, p. 33-44, 2016.

SILVA, I. M. C.; ANDRADE, K. L. Avaliação da qualidade de vida de idosos atendidos em um ambulatório de Geriatria da região nordeste do Brasil. Revista da Sociedade Brasileira de Clínica Médica, São Paulo, v. 11, n. 2, p. 129-34, 2013.

TANAKA, O. Y.; RIBEIRO, E. L. Ações de saúde mental na atenção básica: caminho para ampliação da integralidade da atenção. Ciência \& Saúde Coletiva, Rio de Janeiro, v. 14, n. 2, p. 477-86, 2009. http://dx.doi.org/10.1590/S1413-81232009000200016.

TRENTINI, C. M. et al. Quality of life (QoL) in a Brazilian sample of older adults: the role of sociodemographic variables and depression symptoms. Applied Research in Quality of Life, v. 6, p. 291-309, 2011. 
VITORINO, L. M.; PASKULIN, L. M. G.; VIANNA, L. A. C. Quality of life of seniors living in the community and in long term care facilities: a comparative study. Revista Latino-Americana de Enfermagem, Ribeirão Preto, v. 21, n. esp., p. 3-11, 2013. http://dx.doi.org/10.1590/S0104-11692013000700002.

WORLD HEALTH ORGANIZATION. The World Health Report 2001: Mental health: new understanding, new hope. Geneva: World Health Organization, 2001.

WORLD HEALTH ORGANIZATION. Salud mental: la depresión. Nota descriptiva N$^{\circ} 369$. Geneva: World Health Organization, 2012.

WORLD HEALTH ORGANIZATION. Envelhecimento ativo: uma política de saúde. Brasília: Organização Pan-Americana de Saúde, 2015. 